\title{
SUPPORTING INFORMATION FOR Organochlorine Pesticides in the Soils and Atmosphere of Costa Rica
}

GILLIAN L. DALY ${ }^{\dagger}$ YING D. LEI,${ }^{\dagger}$ CAMILLA TEIXEIRA, ${ }^{\ddagger}$ DEREK C.G. MUIR ${ }^{\dagger}$ LUISA E. CASTILLO,${ }^{\S}$ LIISA M.M. JANTUNEN $\|$, FRANK WANIA ${ }^{\dagger}$

${ }^{\dagger}$ Department of Chemistry and Department of Physical and Environmental Sciences, University of Toronto at Scarborough, 1265 Military Trail, Toronto, Ontario, Canada M1C 1A4

$\$$ Aquatic Ecosystem Protection Research Division, Environment Canada, 867 Lakeshore Road, Burlington, Ontario, Canada L7R 4A6

$\S$ Instituto Regional de Estudios en Sustancias Toxicas, Campus Omar Dengo, Universidad Nacional, Heredia, Costa Rica

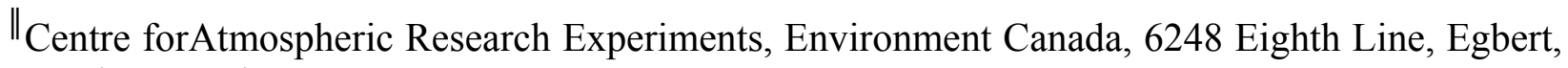
Ontario, Canada LOL 1N0

\begin{tabular}{|l|l|}
\hline $\begin{array}{l}\text { TABLE S1. Elevation and geographical coordinates of the Costa Rica sampling } \\
\text { stations and organic carbon content of the soil samples taken at these Sites. }\end{array}$ & Page S2 \\
\hline FIGURE S1. Topographical map of Costa Rica, showing the sampling stations & Page S3 \\
\hline $\begin{array}{l}\text { FIGURE S2. Back trajectory probability density map for the Irazu station for the } \\
\text { entire sampling period. }\end{array}$ & Page S4 \\
\hline $\begin{array}{l}\text { FIGURE S3. Back trajectory probability density maps for the Monteverde station } \\
\text { for the months of March, June and September } 2004 .\end{array}$ & Page S5 \\
\hline $\begin{array}{l}\text { TABLE S2. Statistical parameters characterizing pesticide distribution across } \\
\text { Costa Rica. }\end{array}$ & Page S6 \\
\hline $\begin{array}{l}\text { FIGURE S4. Pie charts showing the proportion of individual species pp'-DDE, } \\
\text { op'-DDD, op'-DDT and pp'-DDT in air at selected Costa Rican sampling stations. }\end{array}$ & Page S7 \\
\hline TEXT: Air-soil fugacity fraction equations and sensitivity analysis. & Page S8 \\
\hline $\begin{array}{l}\text { TABLE S3. Passive air sampler concentrations (ng-sampler }{ }^{-1} \text { ) of OCPs at 23 } \\
\text { stations across Costa Rica in 2004/2005 }\end{array}$ & Page S9 \\
\hline $\begin{array}{l}\text { TABLE S4. Soil concentrations (pg/g dry weight) of OCPs at stations across Costa } \\
\text { Rica }\end{array}$ & Page S10 \\
\hline
\end{tabular}


TABLE S1 Elevation and Geographical Coordinates of the Costa Rica

Sampling Stations and Organic Carbon Content of the Soil Samples

Taken at these Sites.

\begin{tabular}{|c|c|c|c|c|c|}
\hline no. & name & elevation $^{a}$ & latitude $^{b}$ & longitude $^{b}$ & $\% O C$ \\
\hline 1 & Volcan Barva & 2642 & 10.141 & -84.121 & 16.55 \\
\hline 2 & Carara & 54 & 9.780 & -84.605 & 0.43 \\
\hline 3 & Manuel Antonio & 55 & 9.382 & -84.143 & 4.29 \\
\hline 4 & Playa Naranjo & 2 & 10.780 & -85.667 & 2.03 \\
\hline 5 & Santa Rosa & 308 & 10.840 & -85.618 & 4.69 \\
\hline 6 & Maritza & 600 & 10.957 & -85.496 & 4.79 \\
\hline 7 & Volcan Cacao & 1139 & 10.927 & -85.469 & 7.89 \\
\hline 8 & San Gerardo & 625 & 10.880 & -85.389 & 6.18 \\
\hline 9 & Palo Verde & 17 & 10.344 & -85.340 & 3.72 \\
\hline 10 & Monteverde & 1527 & 10.299 & -84.803 & 18.67 \\
\hline 11 & Santa Elena & 1483 & 10.363 & -84.804 & \\
\hline 12 & Volcan Poas & 2704 & 10.186 & -84.230 & 15.83 \\
\hline 13 & La Selva & 53 & 10.431 & -84.003 & 4.86 \\
\hline 14 & EARTH & 50 & 10.213 & -83.594 & 3.34 \\
\hline 15 & Cahuita & 1 & 9.736 & -82.837 & 8.45 \\
\hline 16 & KeKöldi & 227 & 9.638 & -82.781 & 4.34 \\
\hline 17 & BriBri & 87 & 9.639 & -82.868 & 3.05 \\
\hline 18 & Belen & 935 & 9.167 & -84.309 & 4.70 \\
\hline 19 & San Rafael & 1330 & 9.942 & -84.021 & \\
\hline 20 & Cot & 1831 & 9.89 & -83.880 & \\
\hline 21 & Prusia & 2689 & 9.954 & -83.881 & 1.82 \\
\hline 22 & Irazu & 3390 & 9.98 & -83.837 & 3.11 \\
\hline 23 & Tapanti & 2880 & 9.692 & -83.866 & 12.56 \\
\hline
\end{tabular}

\footnotetext{
${ }^{a}$ in meters above sea level, ${ }^{b}$ Northern latitude and Western longitude in decimal degrees
} 


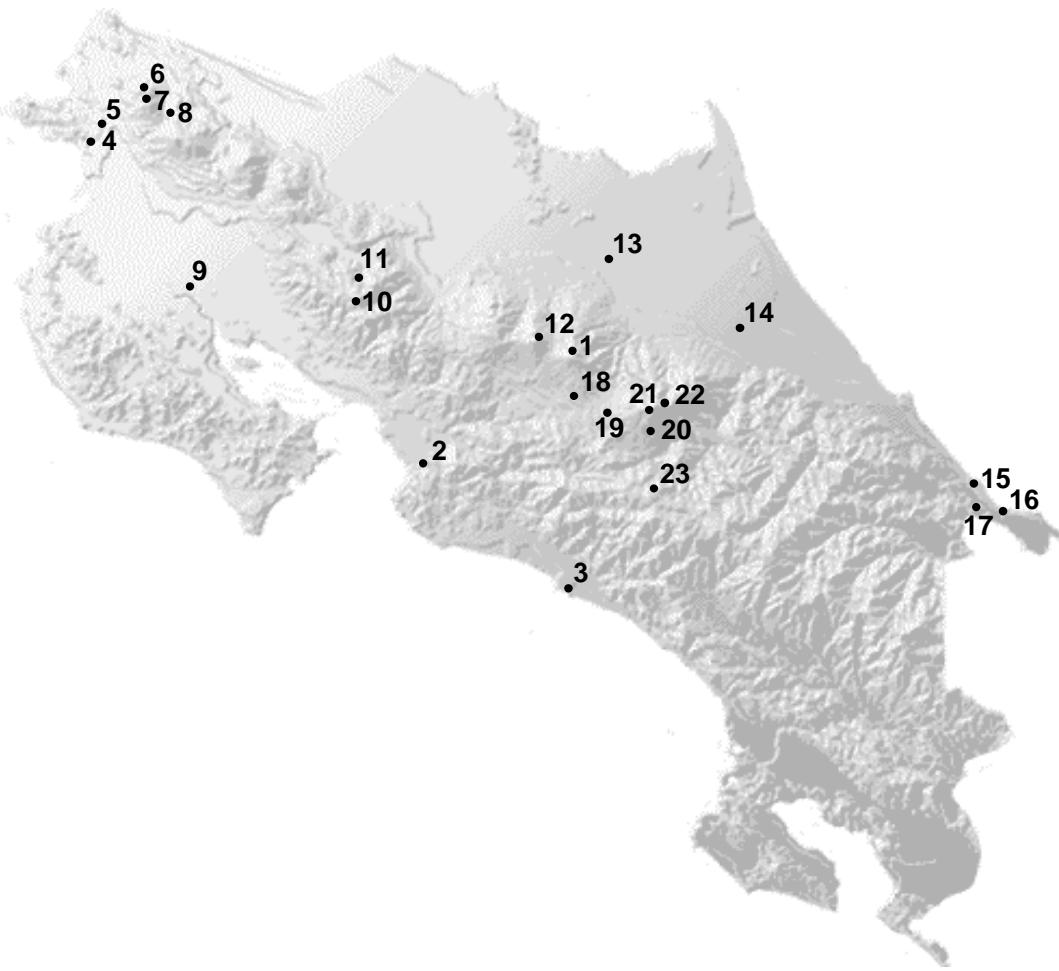

Figure S1 Topographical map (2) of Costa Rica showing the sampling stations, numbered as in Table S1. 


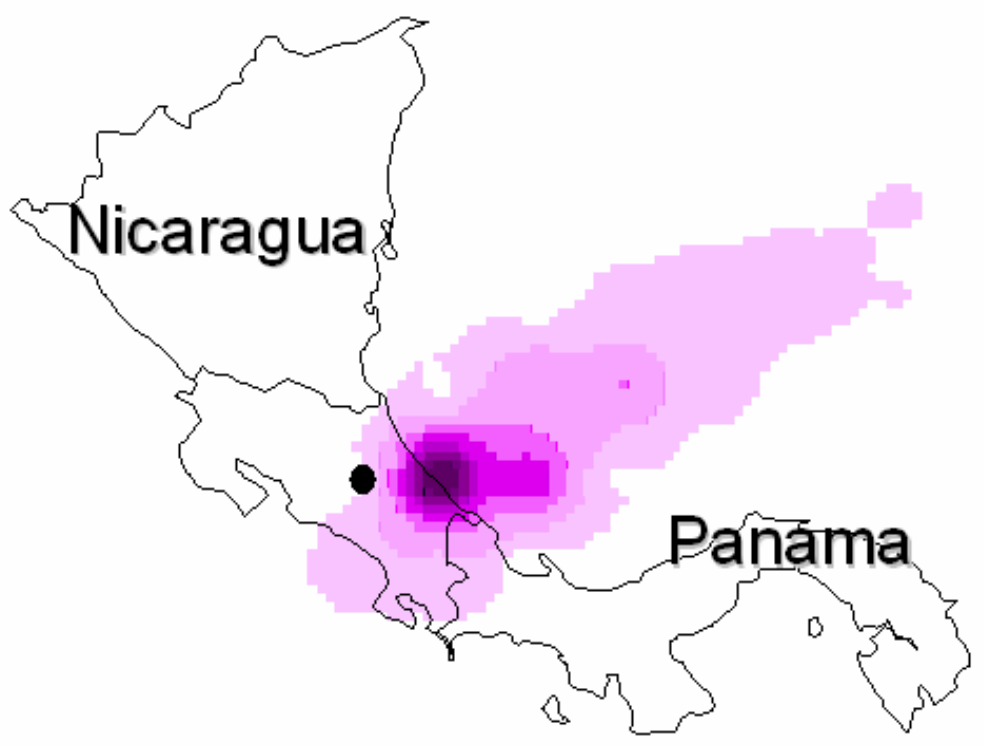

Figure S2 Back trajectory probability density map, or "air shed", for the Irazu station (marked with a black dot) for the entire sampling period (February 2004 to February 2005). The darker the colour, the more probable that air trajectories passed through that spot. The map is generated by compiling 5 day back trajectories taken every 6 hours at 10,100 and $200 \mathrm{~m}$. 
A

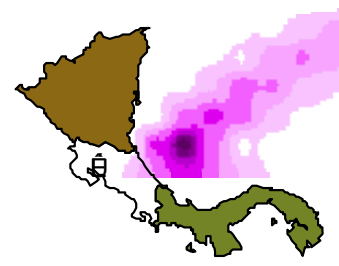

B

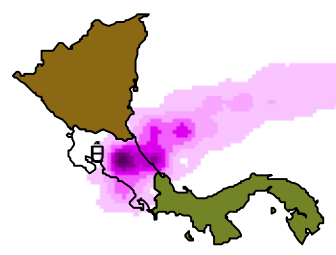

C

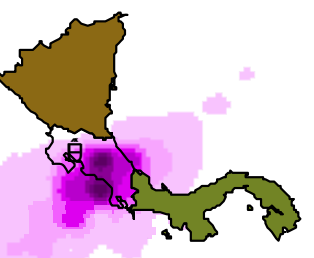

Figure S3 Back trajectory probability density maps for the Monteverde station (marked with a star) for the months of March (A), June (B) and September (C) 2004. The darker the colour, the more probable that air trajectories passed through that spot. The maps are generated by compiling 5 day back trajectories taken every 6 hours at 10, 100 and $200 \mathrm{~m}$. 
TABLE S2. Statistical parameters characterizing pesticide distribution across Costa Rica.

\begin{tabular}{l|llll}
\hline Name & \multicolumn{3}{|c}{ Air } & \multicolumn{2}{c}{ Soila } \\
& Skewness & Kurtosis & Skewness & Kurtosis \\
\hline$\alpha-\mathrm{HCH}$ & 0.87 & 1.69 & & \\
$\gamma-\mathrm{HCH}$ & 2.47 & 6.46 & 2.58 & \\
Aldrin & 1.48 & 1.68 & & \\
Dieldrin & 2.12 & 3.48 & 2.46 & \\
Heptachlor & 2.67 & 6.91 & & \\
heptachlor-epoxide & 4.15 & 18.08 & & \\
trans-chlordane & 2.52 & 6.07 & 2.41 & 8.36 \\
cis-chlordane & 2.93 & 10.17 & 2.72 & 8.37 \\
trans-nonachlor & 3.39 & 12.71 & 2.77 & \\
op'-DDT & 3.93 & 16.36 & & \\
pp'-DDT & 3.09 & 9.81 & & \\
pp'-DDE & 3.95 & 16.37 & & \\
op'-DDD & 1.02 & 1.27 & & \\
\hline
\end{tabular}

aStatistical analysis was not completed for chemicals that were found at fewer than 6 stations 


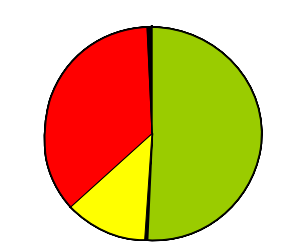

Manuel Antonio
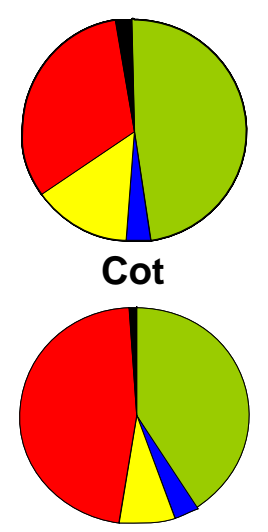

San Gerardo

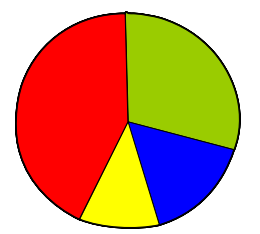

Cahuita
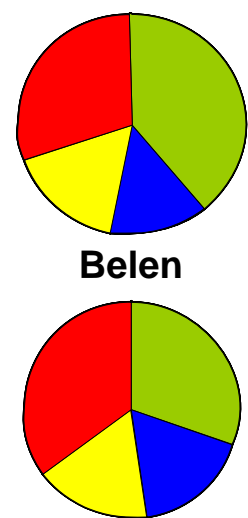

EARTH

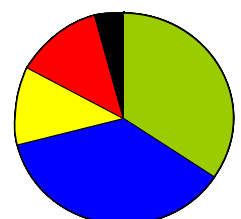

Palo Verde

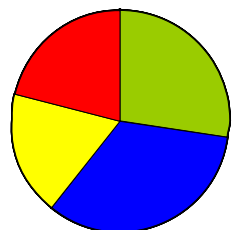

San Rafael

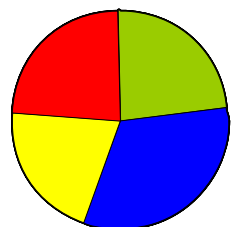

La Selva

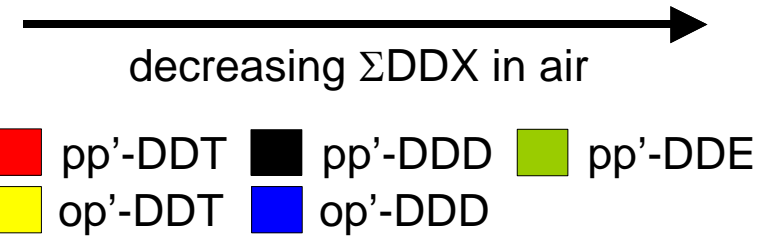

FIGURE S4 Pie charts showing the proportion of individual species pp'-DDE, op'-DDD, op'-DDT and pp'-DDT in air at selected Costa Rica sample stations. Total DDX levels are highest at those stations on the left, and decrease across the row. 
Air-Soil Fugacity Fraction Equations. The fugacity fraction $F$ is calculated from the measured the air and soil concentrations, $C_{\mathrm{A}}$ and $C_{\mathrm{S}}$, in $\mathrm{mol} \cdot \mathrm{m}^{-3}$ :

$F=f_{\mathrm{S}} /\left(f_{\mathrm{S}}+f_{\mathrm{A}}\right)$

where $f_{\mathrm{S}}$ and $f_{\mathrm{A}}$ are the fugacity of a chemical in air and soil in $\mathrm{Pa}$, respectively. $f_{\mathrm{A}}$ is derived from:

$f_{\mathrm{A}}=C_{\mathrm{A}} R T$

where $T$ is the average air temperature in $\mathrm{K}$ and $R$ is the gas constant.

$f_{\mathrm{S}}=C_{\mathrm{S}} R T / E f_{\mathrm{OC}} \rho_{\mathrm{S}} K_{\mathrm{OA}}$

where $E$ is an empirical coefficient relating partitioning into octanol and natural organic matter, $f_{O C}$ is the fraction of organic carbon in soil and $K_{O A}$ is the temperature-dependent octanol-air partition coefficient. The soil concentrations were converted from a mass to volume concentration basis by using a soil solid density $\rho_{\mathrm{S}}$ of $2650 \mathrm{~kg} \cdot \mathrm{m}^{-3}$. A commonly used value for the empirical coefficient $\mathrm{E}$ is 0.411 based on measurements of the sediment-water partitioning of organic chemicals (Karickhoff, S.W. Semi-empirical estimation of sorption of hydrophobic pollutants on natural sediments and soils. Chemosphere 1981, 10, 833-846). Measuring the soil sorption of PCBs from the gas phase to soil, Hippelein and McLachlan (29) found that a coefficient of 0.75 better describes the data.

Uncertainty Analysis for Air-Soil Fugacity Fraction Calculations. In order to calculate the extent of uncertainty in $F$, calculations were repeated while allowing the input parameters to vary. $C_{\mathrm{A}}, C_{\mathrm{S}}$ and $f_{\mathrm{OC}}$ varied by their measured coefficients of variation (using $\mathrm{HCB}$ as an example chemical, this means $15 \%, 32 \%$ and $17 \%$, respectively), $K_{\mathrm{OA}}$ was either a measured (19) or a final adjusted value (25), the empirical factor $E$ was based either on Karickhoff (1981) or ref. (28), and either the maximum or minimum air temperatures (29) were applied. The analysis showed the greatest change in the fugacity fraction $(F \pm 34 \%)$ due to variant $K_{\mathrm{OA}}$ values, while $T$, $C_{\mathrm{S}}, C_{\mathrm{A}}$ and $f_{\mathrm{oc}}$ also created significant differences $(F \pm 32 \%, 25 \%, 13 \%$ and $15 \%$, respectively). When those errors are taken together, they represent a total error of $70 \%$, which means that $F$ between 0.15 and 0.85 do not represent a significant departure from equilibrium. The uncertainty analysis highlights the caution that must be taken in interpreting these fugacity fractions. 
Table S3: Passive air sampler concentrations (ng-sampler-1) of OCPs at 23 stations across Costa Rica in 2004/2005

\begin{tabular}{|c|c|c|c|c|c|c|c|c|c|c|c|c|c|c|c|c|}
\hline ID & Name & $\alpha-\mathrm{HCH}$ & $\gamma-\mathrm{HCH}$ & Ald. & Dield. & HEP & HEPX & TC & $\mathrm{CC}$ & TN & pp'-DDE & pp'-DDD & op'-DDD & op'-DDT & pp'-DDT p & p'-DDD \\
\hline 1 & Volcan Barva & 0.48 & 0.60 & N.D & 0.18 & N.D & 0.22 & N.D. & 0.27 & N.D. & N.D. & N.D. & N.D. & 0.25 & N.D. & N.D. \\
\hline 2 & Carara & 0.55 & 0.81 & 0.2 & 0.17 & 0.0 & 0.14 & 0.19 & 0.05 & 0.11 & 0.21 & N.D. & 0.48 & N.D. & 0.13 & N.D. \\
\hline 3 & Manuel Antonio & 0.98 & 12.1 & N.D & 1.37 & 0.1 & 0.26 & 0.41 & 0.18 & 0.25 & 56.4 & 0.83 & 0.61 & 13.5 & 40.5 & 0.83 \\
\hline 4 & Playa Naranjo & 0.85 & 0.58 & N.D & 0.22 & 0.0 & 0.14 & 0.14 & 0.15 & 0.04 & 0.11 & N.D. & 0.39 & 0.10 & N.D. & N.D. \\
\hline 5 & Santa Rosa & 1.30 & 0.73 & 0.0 & N.D. & N.D & 0.32 & 0.09 & 0.17 & 0.17 & 4.26 & 0.58 & 0.33 & 0.22 & 0.44 & 0.58 \\
\hline 6 & Maritza & 1.26 & 0.70 & 0.1 & 0.21 & 0.1 & 0.33 & 0.38 & 0.35 & 0.24 & 6.71 & 0.28 & 0.08 & 2.22 & 22.7 & 0.28 \\
\hline 7 & Volcan Cacao & 1.21 & 0.81 & N.D & 0.29 & N.D & 0.36 & 0.09 & 0.53 & 0.15 & 0.20 & N.D. & N.D. & 0.19 & 0.27 & N.D. \\
\hline 8 & San Gerardo & 1.11 & 0.71 & N.D & 0.14 & 0.0 & 0.20 & 0.27 & 0.30 & 0.17 & 5.09 & 0.12 & 0.39 & 0.91 & 5.77 & 0.12 \\
\hline 9 & Palo verde & 1.21 & 0.94 & 0.1 & 0.33 & 0.3 & 0.31 & 0.63 & 0.52 & 0.20 & 0.82 & 0.10 & 0.87 & 0.27 & 0.31 & 0.10 \\
\hline 10 & Monteverde & 1.05 & 13.4 & 0.0 & 0.24 & 0.0 & 0.23 & 0.34 & 0.46 & 0.21 & N.D. & N.D. & N.D. & 0.63 & 0.95 & N.D. \\
\hline 11 & Santa Elena ${ }^{4}$ & 1.00 & 0.80 & N.D & 0.33 & 0.0 & 0.28 & N.D. & 0.01 & 0.14 & 0.01 & N.D. & 0.10 & 0.16 & 0.24 & N.D. \\
\hline 12 & Volcan Poas & 0.85 & 0.44 & 0.5 & 0.31 & 0.0 & 0.64 & N.D. & N.D. & 0.04 & 0.52 & 0.43 & N.D. & 0.11 & 0.10 & 0.43 \\
\hline 13 & La Selva & 1.28 & 4.39 & N.D & 0.19 & 0.2 & 0.18 & 0.22 & 0.53 & 0.08 & 0.47 & N.D. & 0.61 & 0.42 & 0.48 & N.D. \\
\hline 14 & EARTH & 1.47 & 0.81 & N.D & 0.46 & 0.8 & 0.23 & 0.40 & 0.41 & 0.17 & 1.35 & N.D. & 0.78 & 0.75 & 1.57 & N.D. \\
\hline 15 & Cahuita & 0.72 & 0.45 & 0.2 & 0.29 & 0.1 & 0.38 & N.D. & 0.19 & 0.12 & 0.95 & N.D. & 0.48 & 0.38 & 1.38 & N.D. \\
\hline 16 & KeKöldi & 1.50 & 0.77 & 0.0 & 0.21 & 0.0 & 0.27 & 0.08 & 0.20 & 0.09 & 0.47 & N.D. & 0.20 & 0.29 & 0.64 & N.D. \\
\hline 17 & BriBri & 0.49 & 0.46 & 0.0 & 0.18 & 0.0 & 0.05 & N.D. & 0.13 & N.D. & 0.90 & 0.17 & 0.82 & 0.48 & 0.57 & 0.17 \\
\hline 18 & Belen $^{4}$ & 2.32 & 32.1 & 0.1 & 3.82 & 3.8 & 0.39 & 3.83 & 2.08 & 0.72 & 2.44 & N.D. & 0.84 & 1.06 & 1.94 & N.D. \\
\hline 19 & San Rafael & 0.74 & 18.6 & 0.4 & 1.7 & 0.8 & 0.43 & 0.95 & 0.44 & 0.35 & 1.31 & N.D. & 1.59 & 0.87 & 1.02 & N.D. \\
\hline 20 & Cot & 1.60 & 8.71 & 0.0 & 5.13 & 2.6 & 2.69 & 2.71 & 1.10 & 1.53 & 15.5 & 0.72 & 1.13 & 4.70 & 10.8 & 0.72 \\
\hline 21 & Prusia & 1.33 & 4.75 & 0.1 & 3.79 & 0.5 & 1.17 & 1.01 & 0.32 & 0.29 & 1.31 & N.D. & 0.23 & 0.47 & 0.20 & N.D. \\
\hline 22 & Irazu & 1.10 & 0.37 & N.D & 0.17 & 0.0 & 8.27 & 0.17 & 0.46 & 0.12 & 0.51 & N.D. & 0.29 & 0.23 & N.D. & N.D. \\
\hline 23 & Tapanti & 0.53 & 0.33 & 0.0 & 0.07 & N.D & 0.03 & N.D. & 0.12 & 0.05 & N.D. & N.D. & N.D. & 0.05 & 0.05 & N.D. \\
\hline & Blank $^{1}$ & N.D. & N.D. & 0.0 & N.D. & 0.0 & N.D. & N.D. & N.D. & 0.00 & N.D. & N.D. & 0.04 & N.D. & 0.03 & N.D. \\
\hline & $\mathrm{MDL}^{2}$ & 0.48 & 0.03 & 0.0 & 0.09 & 0.1 & 0.06 & 0.05 & 0.03 & 0.04 & 0.03 & 0.01 & 0.32 & 0.08 & 0.28 & 0.01 \\
\hline & CV $(\%)^{3}$ & 19 & 17 & 30 & 21 & 18 & 46 & 27 & 41 & 19 & 24 & 27 & 33 & 22 & 37 & 27 \\
\hline
\end{tabular}

${ }^{1}$ Average of 9 resin blanks and 4 field blanks. ${ }^{2}$ Compounds found in blank: MDL $=3 *$ standard deviation, compounds not in blank: MDL $=$ $3 * \mathrm{~S} / \mathrm{N}$. Numbers in italic are below the MDL. ${ }^{3}$ Coefficient of variation between duplicates. ${ }^{4}$ Air samplers at stations 18 (Belen) and 11

(Santa Elena) were deployed later (April 13 and May 16) than the other stations. In order to directly compare contaminant levels measured at Belen and Santa Elena to other sites, they have been scaled up to account for the shorter deployment. 
Table S4: Soil concentrations (pg/g dry weight) of OCPs at stations across Costa Rica, $\mathbf{n}=$ \# of soil samples analyzed.

\begin{tabular}{|c|c|c|c|c|c|c|c|c|c|c|c|c|}
\hline ID & Name & $\mathrm{n}$ & $\alpha-\mathrm{HCH}$ & $\gamma-\mathrm{HCH}$ & Aldrin & Dieldrin & HEPX & $\mathrm{TC}$ & $\mathrm{CC}$ & TN & pp'-DDE & pp'-DDD \\
\hline 1 & Volcan Barva & 2 & 67 & 771 & N.D. & 244 & N.D. & 38 & 22 & 33 & N.D. & N.D. \\
\hline 2 & Carara & 3 & N.D. & 116 & N.D. & N.D. & N.D. & 14 & 8.1 & 6.0 & N.D. & N.D. \\
\hline 3 & Manuel Antonio & 4 & 29 & 247 & 50 & 76 & 40 & 51 & 20 & 34 & 971 & 874 \\
\hline 4 & Playa Naranjo & 2 & N.D. & 208 & N.D. & 54 & N.D. & 17 & 11 & 5.3 & N.D. & N.D. \\
\hline 5 & Santa Rosa & 2 & N.D. & 49 & N.D. & N.D. & N.D. & 4.0 & 1.5 & 2.2 & N.D. & N.D. \\
\hline 6 & Maritza & 2 & N.D. & N.D. & N.D. & N.D. & N.D. & 8.5 & 9.8 & 4.9 & N.D. & N.D. \\
\hline 7 & Volcan Cacao & 3 & N.D. & 122 & N.D. & 27 & N.D. & 15 & 6.6 & 25 & N.D. & N.D. \\
\hline 8 & San Gerardo & 2 & 5.3 & 347 & N.D. & N.D. & N.D. & 16 & 9.9 & 6.7 & N.D. & N.D. \\
\hline 9 & Palo verde & 3 & N.D. & 31 & N.D. & N.D. & N.D. & 1.9 & 7.6 & 3.2 & N.D. & N.D. \\
\hline 10 & Monteverde & 2 & N.D. & N.D. & N.D. & N.D. & N.D. & 11 & 8.5 & 8.3 & N.D. & N.D. \\
\hline 12 & Volcan Poas & 2 & N.D. & 103 & 66 & 512 & N.D. & 17 & 28 & 73 & 719 & 467 \\
\hline 13 & La Selva & 4 & 7.5 & 240 & N.D. & N.D. & N.D. & 9.7 & 7.9 & 4.1 & N.D. & N.D. \\
\hline 14 & EARTH & 3 & N.D. & 104 & N.D. & N.D. & N.D. & 9.7 & 6.2 & 3.9 & N.D. & N.D. \\
\hline 15 & Cahuita & 2 & N.D. & 73 & 45 & N.D. & N.D. & 6.5 & 4.4 & 3.1 & N.D. & N.D. \\
\hline 16 & KeKöldi & 2 & N.D. & 131 & N.D. & N.D. & N.D. & 12 & 8.5 & 4.1 & N.D. & N.D. \\
\hline 17 & BriBri & 2 & N.D. & 179 & N.D. & N.D. & N.D. & 7.9 & 4.4 & 14 & 687 & 454 \\
\hline 18 & Belen & 2 & N.D. & 149 & N.D. & 399 & 39 & 69 & 46 & 166 & 196 & 79 \\
\hline 21 & Prusia & 2 & N.D. & 95 & 200 & 2022 & 55 & 23 & 13 & 78 & 187 & 169 \\
\hline 22 & Irazu & 2 & N.D. & 75 & N.D. & 43 & N.D. & 14 & 10 & 9.6 & N.D. & N.D. \\
\hline 23 & Tapanti & 3 & N.D. & 115 & N.D. & 100 & N.D. & 9.0 & 11 & 11 & N.D. & N.D. \\
\hline & Blank $(\mathrm{pg})^{1}$ & & N.D. & N.D. & N.D. & N.D. & N.D. & N.D. & N.D. & N.D. & N.D. & N.D. \\
\hline & $\begin{array}{l}\text { MDL (pg) } \\
\text { CV }(\%)^{3}\end{array}$ & & $\begin{array}{r}0.1 \\
24\end{array}$ & $\begin{array}{l}0.1 \\
39\end{array}$ & $\begin{array}{r}0.2 \\
17\end{array}$ & $\begin{array}{l}.15 \\
17\end{array}$ & $\begin{array}{r}0.1 \\
15\end{array}$ & $\begin{array}{l}.03 \\
42\end{array}$ & $\begin{array}{r}0.07 \\
40\end{array}$ & $\begin{array}{r}0.03 \\
28\end{array}$ & $\begin{array}{r}0.2 \\
12\end{array}$ & .2 \\
\hline
\end{tabular}

${ }^{1}$ Average of 9 procedural blanks. ${ }^{2}$ Compounds found in blank: $\mathrm{MDL}=3 *$ standard deviation, compounds not in blank: $\mathrm{MDL}=3 * \mathrm{~S} / \mathrm{N}$. All values are below their respective MDL's in pg/g, using the average soil dry weight of 10 grams (i.e. HEPX MDL 0.01 pg/g).

${ }^{3}$ Coefficient of variation between soil samples 